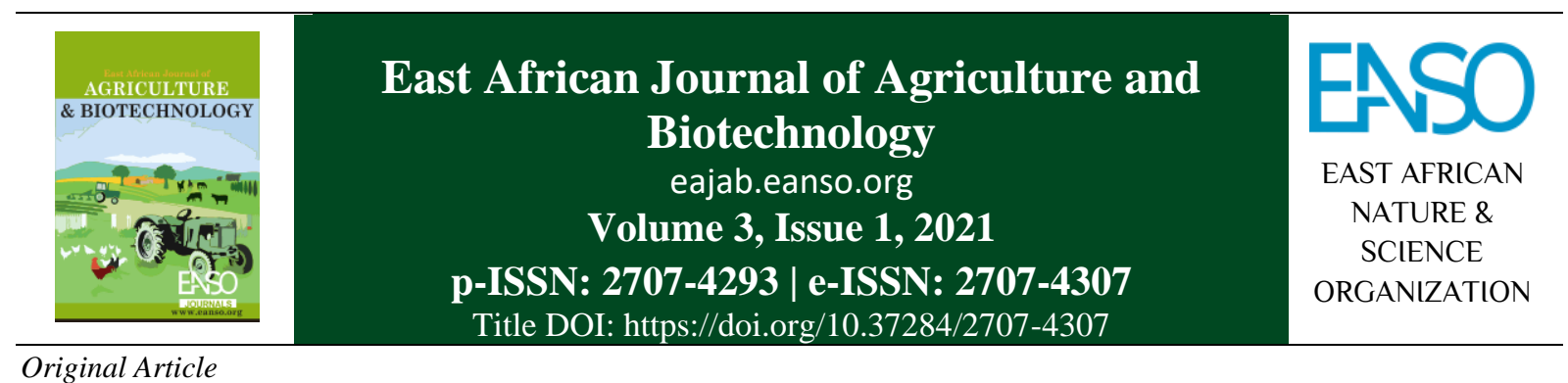

\title{
Assessing Smallholder Farmers' Perception on Climate Variability in Relation to Climatological Evidence: A Case Study of Benguene in the Sudanian Zone of Mali.
}

\author{
Souleymane S. Traore, PhD ${ }^{1}$; Prof. Mamy Soumare, $P h D^{2}$; Sidi Dembele, $P h D^{1}$, ; Vincent \\ N. Ojeh, PhD ${ }^{3}$; Safiatou Guindo, $\mathrm{MSc}^{2}$ \& Prof. Cheick H. Diakite, PhD \\ ${ }^{1}$ Dept. of Geography, University of Social Sciences and Management of Bamako, Mali. \\ ${ }^{2}$ Joint GIS and Remote Sensing Unit, LaboSEP, Institute of Rural Economy, CRRA-Sotuba, Bamako, Mali. \\ ${ }^{3}$ Dept. of Geography, Faculty of Social Sciences, Taraba State University, Jalingo, Nigeria. \\ ORCID ID: https://orcid.org/0000-0002-8373-7205; Correspondent, Email: sstraore@yahoo.fr
}

Article DOI: https://doi.org/10.37284/eajab.3.1.380

Date Published: ABSTRACT

11 August 2021 Sudanian zone is one of the regions in West Africa most confronted with high climate variability, challenging agricultural sustainability and rural livelihoods. Despite multiple research efforts devoted to exploring how Keywords: farmers in this region perceive climate variability and how perceptions relate to adaptive responses, much remains to be done. This study examined farmers' perception of climate variability compared with scientific evidence in the terroir of Benguene, between 1983 and 2018. Data was collected from twentynine (29) farmland heads (representing $49 \%$ of the total farmland heads in the village) through a survey conducted in October 2019. Monthly temperature data from ground measurement and daily rainfall data extracted from the gridded African Rainfall Climatology version 2 (ARC-2) time series was used. Descriptive statistic was used to analyse survey data. Climate data analysis included Mann Kendall trend analysis and computation of growing season parameters (Onset, Duration and Cessation) and its trend. In the end, a conformity index was used to compare farmers' perceptions to climatological evidence. Conformity graph showed that apart from temperature, the farmers have low, to a weak perception of the other variables used to assess their perception. Results showed that many smallholder farmers have observed a rise in temperature (90\%), delay onset $(93 \%)$ and early cessation $(93 \%)$ of rainfall. The analysis of the climate data showed high variability in the climate during the study period as observed in the increasing trends in temperature (pvalue of 0.0007 ) and in the rainfall (p-value of 0.0001). Concerning the season parameters, the results show increasingly early-onset (June 1st \pm 22 days) increasingly late cessation (October 09th \pm 14 days) and consequently a long duration of the rainy season ( $130 \pm 27$ days). Conversely, farmers thought the opposite. These results imply the urgent need to increase smallholder farmers awareness of climate variability and change by providing climate information for better adaptation. 


\section{APA CITATION}

Traore, S. S., Soumare, M., Dembele, S., Ojeh, V. N., Guindo, S., \& Diakite, C. H. (2021). Assessing Smallholder Farmers' Perception on Climate Variability in Relation to Climatological Evidence: A Case Study of Benguene in the Sudanian Zone of Mali. East African Journal of Agriculture and Biotechnology, 3(1), 24-34. https://doi.org/10.37284/eajab.3.1.380

\section{CHICAGO CITATION}

Traore, Souleymane S., Mamy Soumare., Sidi Dembele., Vincent N. Ojeh., Safiatou Guindo., and Cheick H. Diakite. 2021. "Assessing Smallholder Farmers' Perception on Climate Variability in Relation to Climatological Evidence: A Case Study of Benguene in the Sudanian Zone of Mali". East African Journal of Agriculture and Biotechnology 3 (1), 24-34. https://doi.org/10.37284/eajab.3.1.380.

\section{HARVARD CITATION}

Traore, S. J. Soumare, M. Dembele, S. Ojeh, V. N. Guindo, S. \& Diakite, G. H. (2021) “Assessing Smallholder Farmers' Perception on Climate Variability in Relation to Climatological Evidence: A Case Study of Benguene in the Sudanian Zone of Mali”, East African Journal of Agriculture and Biotechnology, 3(1), pp. 24-34. doi: 10.37284/eajab.3.1.380.

\section{IEEE CITATION}

S. J. Traore, M. Soumare, S. Dembele, V. N. Ojeh, S. Guindo \& G. H. Diakite. “Assessing Smallholder Farmers' Perception on Climate Variability in Relation to Climatological Evidence: A Case Study of Benguene in the Sudanian Zone of Mali", $E A J A B$, vol. 3, no. 1, pp. 24-34, Aug. 2021.

\section{MLA CITATION}

Traore, Souleymane S., Mamy Soumare., Sidi Dembele., Vincent N. Ojeh., Safiatou Guindo., and Cheick H. Diakite. "Assessing Smallholder Farmers' Perception on Climate Variability in Relation to Climatological Evidence: A Case Study of Benguene in the Sudanian Zone of Mali". East African Journal of Agriculture and Biotechnology, Vol. 3, no. 1, Aug. 2021, pp. 24-34, doi:10.37284/eajab.3.1.380.

\section{NTRODUCTION}

Good perception of climate and variation variability is a key root to the development of any adaptation strategies by smallholder farmers. It strongly determines how local communities deal with climatic-induced threats and opportunities. The precise nature of their behavioural responses to this perception will shape adaptation options, the processes involved and adaptation outcomes (Adger et al., 2009; Pauw 2013). Misperception about climate change and its associated risk may result in no adaptation or maladaptation, thus, increasing the negative impact of climate change (Grothmann and Patt 2005). The year-to-year variability of rainfall is a significant constraint to the sustainability of the rainfed farming system in most of the Sub-Saharan African (SSA) countries.

In Mali, a West African country, the agriculture sector is the main source of livelihood activities of smallholder farmers, and contributes about $40 \%$ to the country economy (GDP) and employs around $75 \%$ of the economically active workforce (ODHD, 2016). This agriculture is prejudiced by many constraints which are low soil fertility, high demand for food due to high population growth, urbanization and climate variation and change. Despite the wide range of scientific evidence concerning the impacts of climate variability, no much is known about smallholder farmers' perceptions of these impacts on their agricultural practices. Although they study the weather to start their agricultural activities such as ploughing, seeding, etc., the variation in the rainfall regime confuses them most of the time in this planning as tremendous shifts in the rainfall regime have been observed over time. According to Berkes et al., (2000), smallholder farmers already have a fair knowledge about climate variability as part of their traditional ecological knowledge, acquired and transferred through generations. Unfortunately, climate variability and change may continue to affect smallholder farmers' agricultural activities mostly in the Sudanian zone. In this context, numerous researches has been conducted on local farmers' perception of climate change and variability as well as their adaptation strategies (e.g., Ehiakpor et al., 2016; Limantol et al., 2016; Esayas et al., 2019; Tessema and Simane, 2020). Many of these researches show farmer awareness of climate change and variability (Kibue et al., 2016). Some of these findings linked farmer's perception to their knowledge of past climate variability (Amadou et al., 2015). Since the accuracy of farmers' perceptions of climate is critically important if they plan to implement appropriate adaptation measures in their farming activities, much research is still needed in order to increase their awareness of climate variability for building sustainable adaptation strategies. In summary, the purpose of this study is to give a better understanding of farmers' perception of climate

25 | This work is licensed under a Creative Commons Attribution 4.0 International License. 
variability compared with scientific evidence in the terroir of Benguene, between 1983 and 2018.

\section{MATERIALS AND METHODS}

\section{Study Area}

Benguene is a village located about $10 \mathrm{~km}$ from Bla city, Segou region of Mali (Figure 1). The terroir covers an area of approximately $36 \mathrm{sqkm}$, lies between $5^{\circ} 50^{\prime} 40^{\prime \prime} \mathrm{W}$ to $5^{\circ} 53^{\prime} 20^{\prime \prime} \mathrm{W}$ and $12^{\circ} 46^{\prime} 28^{\prime \prime} \mathrm{N}$ to $12^{\circ} 50^{\prime} 40^{\prime \prime} \mathrm{N}$ with an estimated population of 1,905 inhabitants. The climate is semi-arid with annual rainfall ranging from 600 to $800 \mathrm{~mm}$ per year and an average annual temperature which ranges from $22.7^{\circ} \mathrm{C}$ in January as a minimum to $36.1^{\circ} \mathrm{C}$ in May as a maximum
(Traoré et al., 2019). The rainfall regime is monomodal and is characterized by a short rainy season from June to September with a very poor distribution in time and a long dry season from September to May. Harmattan in the dry season and the monsoon in the rainy season are the two high winds that dominate the area. The soils are mostly tropical ferruginous and the natural vegetation is dominated by degraded savannah and the shrub savannah with Guiera senegalensis, Combretum $\quad s p$ and Anogeissus leiocarpus as the most popular species. The population of the study site was mainly farmers and herders who earned their living through rainfed agriculture (dominated by the cultivation of Millet and Sorghum and Cotton), herding and provisioning ecosystem services from the trees.

\section{Figure 1: Map showing the study area}

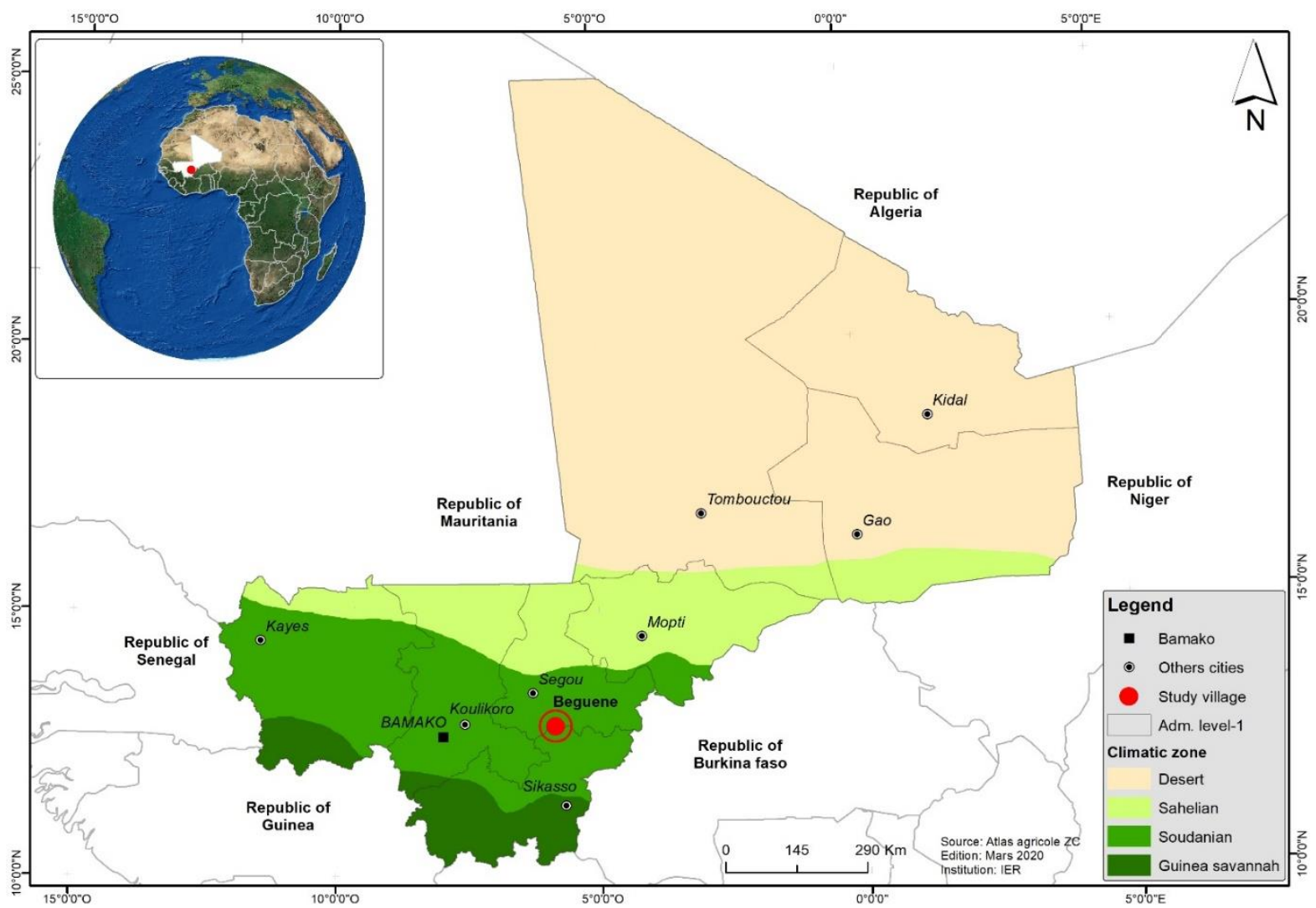

\section{Data Collection}

The study used data collected from farmers' household survey, combined with historical climate data. The farm survey was conducted using a standard structured questionnaire applying both qualitative and quantitative methods of data collection about: demographic characteristics, perceptions of rainfall amount, onset, cessation, duration and dry spell, temperature variation over the last 30-years. The household data were collected from the Support Project to Improve the Governance of the Cotton Sector in its New Institutional Configuration and the Productivity and Sustainability of Farming Systems in the Cotton Zone PASE-II project Research and Development component "PASE-II/R\&D" database, where the questionnaire survey was conducted. The survey was conducted in October 2019 and involved 29 over 59 heads of farmland

26 | This work is licensed under a Creative Commons Attribution 4.0 International License. 
representing $49 \%$ of the total farmland heads of the village. Systematic sampling method was used to identify the households by applying the simple equation following (Taifa and Desai, 2016):

$$
n=\frac{N}{1+N e^{2}}
$$

where $\mathrm{n}=$ sample size, $\mathrm{N}=$ total population, $\mathrm{e}=$ margin error (5\% in this research). Since this sample size does not depend only on the size of the total population, therefore a corrective factor was applied using the equation of (Slimani, 2014) as follow:

$n^{\prime}=\frac{N \times n}{N+n}+1$

Where $\mathrm{n}^{\prime}=$ readjusted sample size, $\mathrm{N}=$ total population and $\mathrm{n}=$ sample size from the $1^{\text {st }}$ equation.

Climate data include monthly mean temperature and daily rainfall records from 1983 to 2018 . However, due to the absence of temperature data at the Bla met station, the nearest station, temperature data recorded at the Segou station about $70 \mathrm{~km}$ distance from the Bla station was collected. The daily rainfall data was extracted from the $11 \mathrm{~km}$ gridded African Rainfall Climatology version 2 (ARC-2) database for Bla station. The ARC-2 is a satellite-based daily rainfall dataset available from 1983 - present at a $0.1^{\circ} \times 0.1^{\circ}$ spatial resolution for the whole continent. This data builds on ARC-1 that is developed using the algorithm applied in the Rainfall Estimation version 2 (RFE-2) which is found to be amongst the most reliable products of satellite base datasets covering Africa (Love et al., 2004). According to (Love et al., 2004) the difference as compared to RFE- 2 is that ARC-1 uses only gauge and infra-red data whereas RFE2 uses additional microwave data, which is not available prior to 1995 . In the end, ARC-2 is a new version of ARC-1 with a recalibration of the 1983-2005 period (Novella and Thiaw, 2012).

\section{Data Analysis}

\section{Survey data}

Data from the questionnaires were categorized based on farmers' perceptions of the onset season, seasonal rainfall amount, duration, cessation of rainy season and variability in the study area. Thereafter, data was verified by checking the categories of all variables for correction. Then, the corrected data were analysed through a descriptive statistic and cross-tabulation. Tables, figures, frequencies distribution and percentages were used to present the results. In the next step, the consistency of smallholder farmers' perception was assessed using the Informant Consensus Factor (ICF) proposed by Heinrich et al., (1998) and Canales et al., (2005) as follow:

$I C F=\frac{N U R-N t}{N U R-1}$

This factor allows appreciating the diversity and consistency of the indicators of change. With $N U R$ : number of answers in each category of indicators of change; $N t$ : number of variants in each category. The value of the ICF varies between 0 and 1 and indicates a highest consensus when it tends towards 1. Lastly, the perception of the smallholder farmers was compared to the climatological evidence through a conformity graph.

\section{Climate data}

The 35-years rainfall and temperature data were used to compute the annual average temperature (minimum and maximum) and rainfall. Some other parameters related to the rainy season, such as onset, cessation of rainy season and duration of the rainy season and intra-seasonal drought spell were computed over the study period. These parameters based on daily rainfall were defined to characterize the rainfall regime (Table 1). From the wide definitions of such parameters (Marteau et al., 2010; Sivakumar, 1988; Stern et al., 2005, Fitzpatrick et al., 2015, Zhang and al., 2017), this research used the ones proposed by Zhang and al., (2017) with moderate modification given the climatic context of the area. So, the onset of the rainy season is considered as the first occurrence of at least $20 \mathrm{~mm}$ cumulative rainfall within 7 days after May 1; followed by a total of $20 \mathrm{~mm}$ rainfall within the next 20 days. The end of the rainy season is determined by the occurrence of 20 consecutive days with cumulated rainfall less than $10 \mathrm{~mm}$ after the 1st September. The duration of the rainy season is defined as the number of days between the onset and cessation of the rainy season. Stern et al., (2005) defined dry spell as consecutive days without rain. Since a long dry spell after the start of onset of the rainy season causes a 'false start' its consideration in this analysis is very important. Based on this

27 | This work is licensed under a Creative Commons Attribution 4.0 International License. 
importance, the dry spell was computed during the next thirty days after the onset of the rainy season. In the end, trends of these parameters related to the rainy season were estimated using Sen's slope and assessed using a non-parametric MannKendall test (Kendall, 1938; Mann, 1945).

Table 1: Summary of rainfall variables applied

\begin{tabular}{|c|c|}
\hline Variables & Definition \\
\hline Onset of rainy season & $\begin{array}{l}\text { The first occurrence of at least } 20 \mathrm{~mm} \text { cumulative rainfall within } 7 \text { days } \\
\text { after May } 1 \text {, followed by a total of } 20 \mathrm{~mm} \text { rainfall within the next } 20 \text { days. }\end{array}$ \\
\hline $\begin{array}{l}\text { Cessation of rainy } \\
\text { season }\end{array}$ & $\begin{array}{l}\text { urrence of } 20 \text { consecutive days with cumulated rainfall less than } \\
\text { after September } 1 .\end{array}$ \\
\hline Length of rainy season & Number of days between the onset and the cessation of the rainy season. \\
\hline Intra-seasonal dry spells & $\begin{array}{l}\text { The number of dry spells during rainy season during the next thirty days } \\
\text { after the onset of rainy season. }\end{array}$ \\
\hline
\end{tabular}

\section{RESULTS}

\section{Characteristics of respondents}

From the total farm head, about $41 \%$ were literate and $48 \%$ of the respondents were illiterate with no formal education. The ages of the respondents range from 40 to 75 years old. Also, about $7 \%$ of the respondents were below 50 years old; $38 \%$ were between 50 to 60 years old; $38 \%$ were between 60 to 70 years old and $17 \%$ were above 70 years old (Table 2 ).

Table 2: Demographic characteristics of respondents

\begin{tabular}{lll}
\hline Variables & Frequency & Percentages \\
\hline Level of education farm head & & \\
\hline Primary & 0 & 0 \\
Secondary & 1 & 3 \\
High School & 0 & 0 \\
Literate & 12 & 41 \\
Arabic & 2 & 7 \\
None & 14 & 48 \\
\hline Age of farm head (year) & & \\
\hline$<50$ & 2 & 7 \\
$50-60$ & 11 & 38 \\
$60-70$ & 11 & 17 \\
$>70$ & 5 & \\
\hline Farmland size (nb. of person) & & 28 \\
1 to 10 & 8 & 38 \\
11 to 20 & 11 & 13 \\
20 to 30 & 4 & 21 \\
31 and plus & 6 & \\
\hline
\end{tabular}

\section{Perceptions of farmers on climate variability}

The perception of farmers constitutes the local knowledge based on lived experiences to explain and understand climate recent evolution. The main perceptions of the variability and climatic variations of the populations of Benguene refer to a recent evolution over the last 30 years and relate to precipitation and temperatures. The smallholder farmer's perception of climate variability in this study is related to the variability of various parameters which are rainfall amount per year, the onset of the rainy season, cessation of the rainy season, drought spell and the average temperature. Farmers were asked about their perception of the year-to-year variations in temperature and rainfall for the past 30 years and the results are presented in (Table 3 ). The results reveal that a slightly higher proportion of farmers claimed that temperature is increasing and rainfall is decreasing and noted the late-onset and early cessation of the rainy season which is indicative of a shorter duration of the rainy season. The

28 | This work is licensed under a Creative Commons Attribution 4.0 International License. 
majority of Farm heads perceived a decrease in rainfall amount during the last 30-year.

Table 3: Farmer perception of variation in climate variables and rainy season parameters

\begin{tabular}{lllll}
\hline Variable & Perceptions & Frequency & Percentage & FCI \\
\hline \multirow{4}{*}{ Temperature } & Rise & 26 & 90 & 0.88 \\
& Decrease & 1 & 3 & 0 \\
& Stable & 2 & 7 & 0 \\
& Don't know & 0 & 0 & 0 \\
\hline \multirow{5}{*}{ Rainfall amount } & Increase & 0 & 0 & 0 \\
& Decrease & 28 & 97 & 0.89 \\
& Stable & 1 & 3 & 0 \\
& Don't know & 0 & 0 & 0 \\
\hline \multirow{5}{*}{ Onset of season } & Early & 2 & 7 & 0 \\
& Late & 26 & 90 & 0.88 \\
& Regular to normal & 0 & 0 & 0 \\
& Don't know & 1 & 3 & 0 \\
\hline \multirow{5}{*}{ Cessation of rainy season } & Early & 27 & 93 & 0.88 \\
& Regular to normal & 0 & 0 & 0 \\
& Late & 0 & 0 & 0 \\
& Don't know & 2 & 7 & 0 \\
\hline \multirow{5}{*}{ Duration of rainy season } & Normal & 1 & 3 & 0 \\
& Short & 26 & 90 & 0.88 \\
& Long & 1 & 3 & 0 \\
& Don't know & 1 & 3 & 0 \\
\hline \multirow{5}{*}{ Dry spell within the rainy season } & Some times & 10 & 34 & 0.67 \\
& Never & 0 & 0 & 0 \\
& Regular & 14 & 48 & 0.76 \\
\hline Total respondent & Don't know & 5 & 17 & 0 \\
\hline \multirow{5}{*}{} & & & & 29 \\
\hline
\end{tabular}

\section{Trend in rainfall, temperature and rainy} season parameters

The mean annual rainfall in the area for the period 1983-2018 was $714 \mathrm{~mm}$ per year. The lowest and highest annual rainfall amounts for the same period were 403 and $1000 \mathrm{~mm}$ and occurred in
1977 and 2015 respectively. The Mann-Kendall test, performed on the annual precipitation and temperature series with the purpose to test the presence or absence of a significant trend in this data series, confirms an increasing trend at a confidence level of $95 \%$ (Fig.2).

Figure 2: Annual rainfall trend; 1983-2018

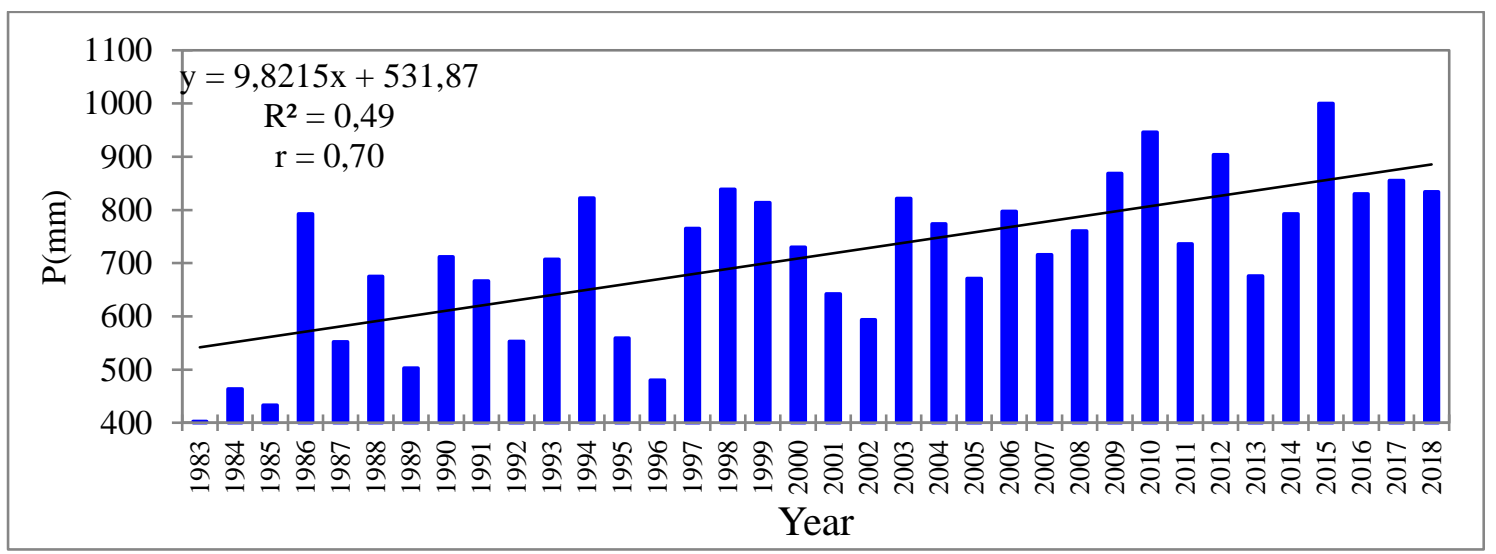

29 | This work is licensed under a Creative Commons Attribution 4.0 International License. 
Annual temperature for the area over the period 1983-2018 (Fig.3) indicates that temperature has continuously increased. The mean annual temperature over this time period was $29.5^{\circ} \mathrm{C}$. The lowest and the highest of the mean monthly temperatures within the period (1983-2018) were $22.50^{\circ} \mathrm{C}$ and $34.0^{\circ} \mathrm{C}$ and occurred in January 1987 and April 1998 respectively. The highest temperatures occurred in April and May with mean values of $33.80^{\circ} \mathrm{C}$ and $34.0^{\circ} \mathrm{C}$ respectively and the lowest were observed to occur in December and January, with long-term (19832018) average values of mean monthly minimum temperatures of 25.8 and $25.0^{\circ} \mathrm{C}$ respectively. The non-parametric Mann-Kendall test confirms this trend at a confidence level of $95 \%$.

\section{Figure 3: Trend in monthly temperature from 1983-2018}

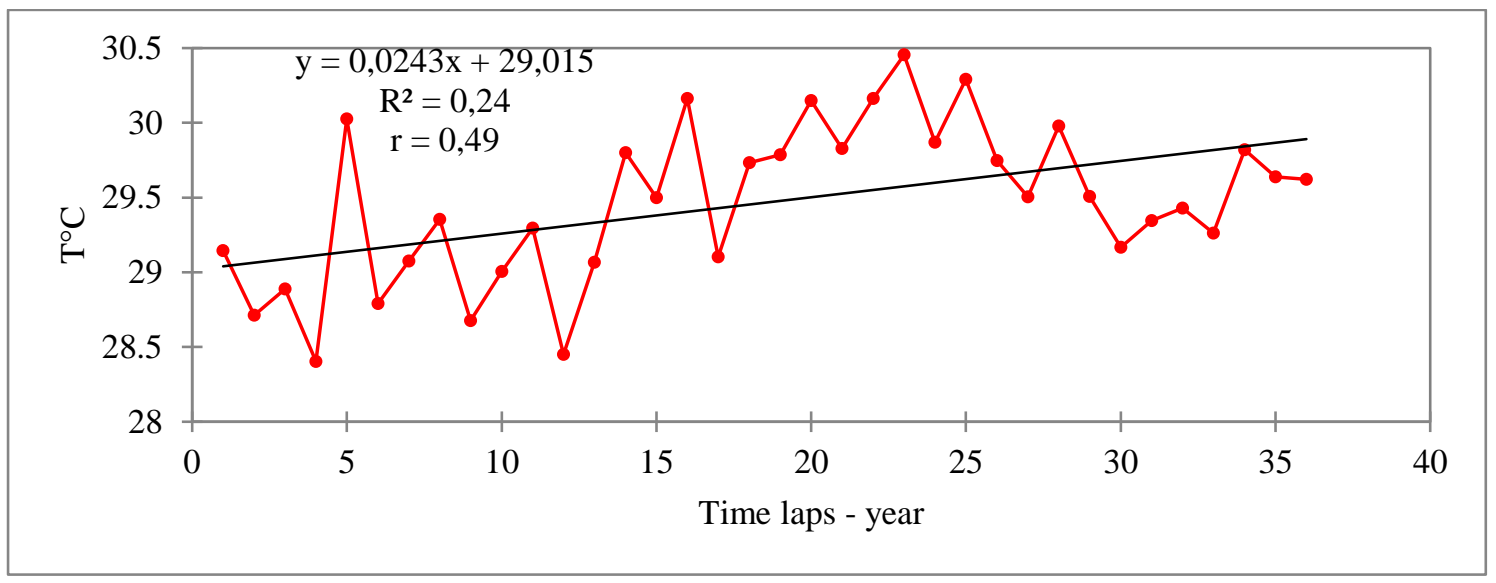

There is an obvious pattern of variation in the date of onset of the rainy season over the area. Analysis of the inter-annual variability of the onset and the cessation of the rainy season during the period 1983-2018 (Fig.4) exhibited an early onset and a late cessation. The variation of rainy season onset ranges from 123 days of the year (May 2nd) and 185 days of the year (July 13th) with an average of $153 \pm 22$ days of the year (June 1st \pm 22 days). The early onset dates were observed in 1993 and 2003, however, the late-onset dates were observed in 1989 and 1990. By considering the trend line, it can be deduced that the onset is getting earlier and earlier even it's not significant $(\mathrm{r}=0.33)$. Contrary to the onset, the cessation of the rainy season goes from 259 to 308 days of the year, specifically between September 15th (early cessation) and November 03rd (late cessation) with an average end date around $282 \pm 14$ days of the year (October 09th \pm 14 days). The early cessation dates were observed in 1983; 1985; 1987 and 1992 and the latest cessation date was observed in 2005. From the trend line, it can be assumed that cessation is increasingly late $(r=0.50)$. As a consequence of the observed early onset and the late cessation, the duration of the rainy season showed an increase $(r=0.55)$. The low duration was 74 days, i.e., 2 months and 13 days observed in 1989 and the high duration was 173 days, i.e. 5 months and 20 days observed in 2006 with an average duration of $130 \pm 27$ days.

\section{Figure 4: Variability of rainy season parameters (Onset and Cessation) in Benguene area}

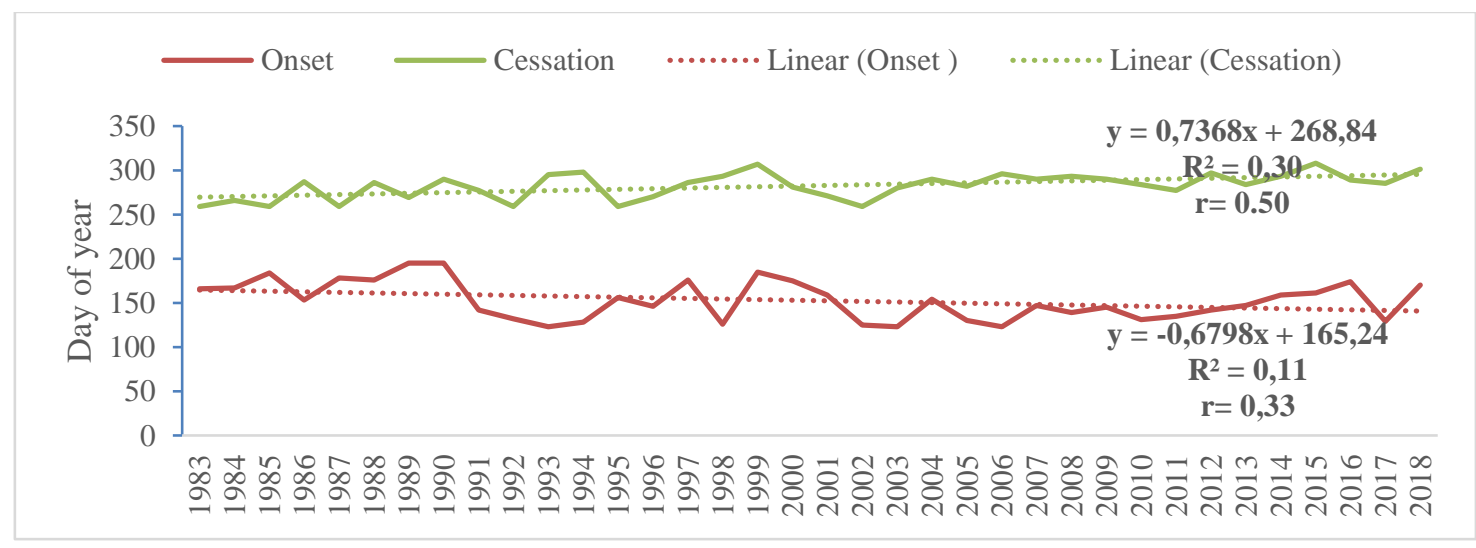

30 | This work is licensed under a Creative Commons Attribution 4.0 International License. 
Comparison of smallholder farmer perception with climatological evidence

The perception of climate variation and variability is defined on the right awareness of a farmer about the following five climatic parameters: rainfall amount, temperature, onset, duration and the end of the rainy season, which were based on the historical climate records. Figure (5) shows the agreement and discordance of the answers given by smallholder farmers concerning the observed climatic data. The results showed that none of the respondents had a good perception of climate variability and variations in general. With some variables such as temperature, the majority of the respondents has a good perception of its evolution compared to climatic records. Regarding the cumulative rainfall, the duration and the cessation of the rainy season, analyses of climate data have shown an increase, while smallholder farmers perceived a decrease. Analyses have also shown an early onset of the season dates when smallholder farmers supposed the opposite.

\section{Figure 5: Conformity graph of farmer perception against climatological evidence}

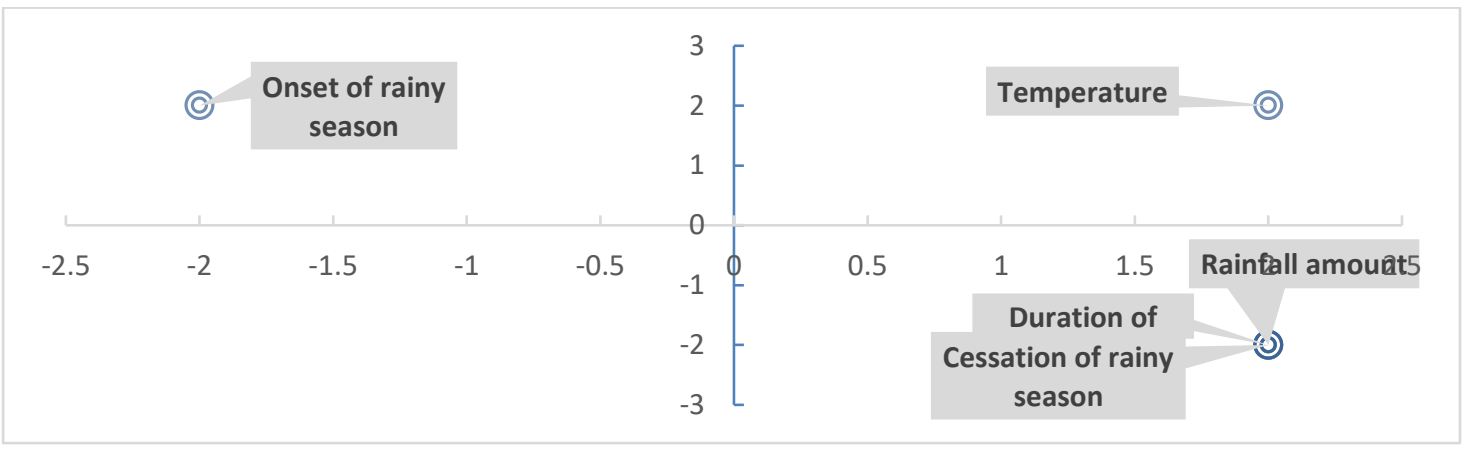

\section{DISCUSSION}

Rainfall recovery in West Africa was already asserted by Nicholson et al 2018; Lalou et al. 2019; Sanogo et al. 2015. The analysis of climatic data showed a significant upward of both annual rainfall amount $(\mathrm{p}<0.5)$ and monthly mean temperature $(\mathrm{p}<0.5)$ in the study area. Similarly, season parameters showed also increasingly early onset dates, later and cessation dates resulting in long durations of the rainy season. These results agree somewhat with the conclusions of Ouoba (2013) who noted the dates of early-onset and late-onset in the Burkina Faso Sahel, even this trend was so weak. Authors such as Niang et al. 2014 indicate increasing trends in temperatures in Africa, and projections by James and Washington (2013) reported that these trends are likely to continue and increase faster than the world average.

Farmers used the term "poor season" to refer to any year with reduced crop production due to insufficient rainfall and other crop production constraints. From the analysis, the large majority of respondents in the study area believed to have experienced climate change during the study period. The targeted Farm heads indicated that they perceived an increase in temperature and decrease in rainfall; and late-onset and early cessation with short rainy seasons in consequence. Comparable expressions of awareness by farmers about climate change were reported in studies conducted over the recent year in, Ethiopia (Esayas et al., 2019; Temessa and Simane, 2020), Nigeria (Ayanlade et al., 2017); Ghana (Ehiakpor et al., 2016; Limantol et al., 2016, Amadou et al., 2015). Some of these research such as (AsareNuamah and Botchway, 2017; Ayanlade et al., 2017; Amadou et al., 2015) attempted to relate perceptions of climate change to actual climatic data from meteorological sources.

The major conclusion from this study was that the farmers' perceptions of rainfall amount and pattern did not correspond with climatic trends. Therefore, farmers in Benguene may not be a reliable source of long-term changes in rainfall, but they could provide reliable information on inter-and intra-seasonal rainfall changes. Authors such as Makuvaro et al., (2018) suggest studies on comparisons of perceptions and trends based on smaller time scales rather than long periods. This is particularly important when such studies seek communities' responses.

On the other hand, the analysis showed a significant rise in monthly temperature and was in total agreement with smallholder farmer's

31 This work is licensed under a Creative Commons Attribution 4.0 International License. 
perception. This result is in agreement with studies conducted in Ghana (Amadou et al., 2015, Asare-Nuamah), Niger (Assoumana et al., 2016), Nigeria (Ayanlade et al., 2017) and central Zimbabwe (Makuvaro et al., (2018). On the contrary Ouedraogo et al., (2010); Ulrich et al., (2015); Bambara, et al., (2016) reported that farmers perceive changes in climatic variables such as a decrease in rainfall, an increase in temperature, the late or early start of the season and the short duration of the season, etc., which was in contradiction with our results. The divergence of the results may be due to the low level of education of respondents in the survey.

Understanding how the local population perceive climate variability and change is essential to develop effective adaptation strategies. Then it will be reasonable to expect more willingness of farmers to adopt farming practices to mitigate associated adverse effects since they have good perception of this climate variability and change (Chaudhary et al., 2011). Given the contradiction between climate data and farmer perception in the study area, access to climate information and forecast is a critical component for sustainable adaptation.

\section{CONCLUSION}

This study has analyzed trends of climate variability and farmers' perception in Benguene terroir, Mali using meteorological time series data from 1983 to 2018. Understanding the temperature and rainfall variability trends and farmers' perception of changes in the climate would offer valuable information for planning and implementing local-level adaptations. The study revealed that the perception of most farmers was an existence of an increasing pattern in temperature and a decrease in the pattern in precipitation in the study area for the past 40-year. Smallholder farmers have perceived a reduction in rainfall, an increase in temperature, late-onset, and early cessation of the rainy season. The results have shown that there had been a change in temperature and rainfall over time and there was some contradiction between farmers' perception and the analyzed historical meteorological data. The Mann-Kendall trend analysis confirms a significant upward trend in the annual mean temperature as well as in the annual rainfall amount. Generally, from these findings, the study concludes that climate variability and change will hurt the livelihoods of smallholder farmers because of their weak perceptions. Therefore, based on this conclusion the study advises strengthening local skill and awareness by providing climate information for better adaptation to climate variability and change.

\section{ACKNOWLEDGEMENTS}

The authors express their gratitude to the French Development Agency (AFD) which funded this research as part of the Productivity Improvement Project in the Cotton Zone of Mali (PASE II) / and the Support Project for agroecological transition in the cotton zone of Mali: AgrECo CML1430. The authors also thank the local community of Benguene who agreed to provide their knowledge pro bono for the love of science.

\section{REFERENCES}

Adger, W. N., Dessai, S., Goulden, M., Hulme, M., Lorenzoni, I., Nelson, D. R., ... \& Wreford, A. (2009). Are there social limits to adaptation to climate change? Climatic change, 93(3), 335-354. https://doi.org/10.1007/s10584-0089520-z.

Amadou, M. L., Villamor, G. B., Attua, E. M., \& Traoré, S. B. (2015). Comparing farmers' perception of climate change and variability with historical climate data in the Upper East Region of Ghana. Ghana Journal of Geography, 7(1), 47-74.

Asare-Nuamah, P., \& Botchway, E. (2019). Comparing smallholder farmers' climate change perception with climate data: the case of Adansi North District of Ghana. Heliyon, 5(12), 1- 12. https://doi.org/10.1016/j.heliyon .2019.e03065.

Assoumana, B, T., Ndiaye, M., Puije, G. V. D., Diourte, M., \& Gaiser, T. (2016). Comparative Assessment of Local Farmers' Perceptions of Meteorological Events and Adaptations Strategies: Two Case Studies in Niger Republic. Journal of Sustainable Development; 9, (3), 118-135. http://hdl.handle.net/123456789/4513.

Ayanlade, A., Radeny, M., \& Morton, J. F. (2017). Comparing smallholder farmers' perception of climate change with meteorological data: A case study from southwestern Nigeria. Weather and climate extremes, 15, 24- 
33. https://doi.org/10.1016/j.wace.2016.12.00 1.

Bambara, D., Thiombiano, A., \& Hien, V. (2016). Changements climatiques en zones nordsoudanienne et sub-sahélienne du Burkina Faso : comparaison entre savoirs paysans et connaissances scientifiques. Revue d'Ecologie (Terre et Vie), 71(1), 35-58. http://hdl.handle.net/2042/58188.

Berkes, F., Colding, J., \& Folke, C. (2000). Rediscovery of traditional ecological knowledge as adaptive management. Ecological applications, 10(5), 1251-1262. https://doi.org/10.1890/1051- 0761(2000)010[ 1251:ROTEKA]2.0.CO;2.

Canales, M., Hernández, T., Caballero, J., De Vivar, A. R., Avila, G., Duran, A., \& Lira, R. (2005). Informant consensus factor and antibacterial activity of the medicinal plants used by the people of San Rafael Coxcatlán, Puebla, México. Journal of Ethnopharmacology, 97(3), 429-439. https://doi.org/10.1016/j.jep.2004.11.013.

Chaudhary, P., Rai, S., Wangdi, S., Mao, A., Rehman, N., Chettri, S., \& Bawa, K. S. (2011). Consistency of local perceptions of climate change in the Kangchenjunga Himalaya landscape. Current Science, 101(4), 504-513. https://www.jstor.org/stable/24078981.

Ehiakpor, D. S., Danso-Abbeam, G., \& Baah, J. E. (2016). Cocoa farmer's perception on climate variability and its effects on adaptation strategies in the Suaman district of western region, Ghana. Cogent Food \& Agriculture, 2(1), 1- 12. http://dx.doi.org/10.1080/233119 32.2016.1210557.

Esayas, B., Simane, B., Teferi, E., Ongoma, V., \& Tefera, N. (2019). Climate Variability and Farmers' Perception in Southern Ethiopia. Advances in Meteorology, 2019, 1-19. https://doi.org/10.1155/2019/7341465.

Fitzpatrick, R. G., Bain, C. L., Knippertz, P., Marsham, J. H., \& Parker, D. J. (2015). The West African monsoon onset: A concise comparison of definitions. Journal of Climate, 28(22), 8673- 8694. https://doi.org/10.1175/J CLI-D-15-0265.1.
Grothmann, T., \& Patt, A. (2005). Adaptive capacity and human cognition: The process of individual adaptation to climate change. Glob Environ Chang, 15:199-213.

Heinrich, M., A. Ankli, Frei, B., Weimann, C., \& Sticher, O., (1998). Medicinal plants in Mexico: Healers'consensus and cultural importance, Social Science and Medicine, 47, 1863-1875.

James, R. \& Washington, R. (2013). Changes in African Temperature and Precipitation Associated with Degrees of Global Warming, Climatic Change 117 (4): 859-872.

Kendall, M. G. (1938). A new measure of rank correlation," Biometrika, vol. 30, no. 1-2, 8193.

Kibue, G. W., Liu, X., Zheng, J., Zhang, X., Pan, G., Li, L., \& Han, X. (2016). Farmers' Perceptions of Climate Variability and Factors Influencing Adaptation: Evidence from Anhui and Jiangsu, China. Environmental Management, 57, 976-986 https://doi.org/10.1007/s00267-016-0661-y.

Lalou, R., Sultan, B., Muller, B., \& Ndonky, A. (2019). Does climate opportunity facilitate smallholder farmers' adaptive capacity in the Sahel? Palgrave Commun 5, 81.

Limantol, A.M., Keith, B.E., Azabre, B.A., \& Lennartz, B. (2016). Farmers' perception and adaptation practice to climate variability and change: a case study of the Vea catchment in Ghana. SpringerPlus 5, 830. https://doi.org/10.1186/s40064-016-2433-9.

Love, T. B., Kumar, V., Xie, P., \& Thiaw, W. (2004). A 20-year daily Africa precipitation climatology using satellite and gauge data. In: Proceedings of the $84^{\text {th }}$ AMS Annual Meeting, Vol. Conference on Applied Climatology, Seattle, WA-(CD-ROM).

Makuvaro, V., Murewi, C. T., Dimes, J., \& Chagonda, I. (2018). Are smallholder farmers' perceptions of climate variability and change supported by climate records? A case study of lower Gweru in semiarid central Zimbabwe. Weather, Climate, and Society, 10(1), 35-49.

Mann, H. B. (1945). Nonparametric tests against trend. Econometrica: Journal of the econometric society, 12(3), 245-259.

33 This work is licensed under a Creative Commons Attribution 4.0 International License. 
Marteau, R., Sultan, B., Moron, V., Baron, C., Traoré, S. B., \& Alhassane, A. (2010, September). Démarrage de la saison des pluies et date de semis du mil dans le sud-ouest du Niger. In XXIIIe colloque de l'Association Internationale de Climatologie. Risques et changement climatique (pp. 379-384).

Niang, I., Ruppel, O. C., Abdrabo, M. A., Essel, A., Lennard, C., \& Padgham, J. (2014). Africa in: Barros VR, Field CB, Dokken DJ, Mastrandrea MD, Mach KJ, Bilir TE, et al., editors. Climate change 2014: impacts, adaptation, and vulnerability. Part B: regional aspects. Contribution of working Group II to the fifth assessment report of the Intergovernmental Panel on Climate Change. Cambridge, UK and New York, NY.

Nicholson, S. E., Fink, A. H., \& Funk, C. (2018). Assessing recovery and change in West Africa's rainfall regime from a 161-year record. International Journal of Climatology, 38(10), 3770- 3786. https://doi.org/10.1002/j oc. 5530 .

Novella, N. S., \& Thiaw, W. M. (2013). African rainfall climatology version 2 for famine early warning systems. Journal of Applied meteorology and Climatology, 52(3), 588-606. https://doi.org/10.1175/JAMC-D-11-0238.1.

ODHD (2016). Rapport national sur le développement humain, édition2016, Migration, développement et lutte contre la pauvreté. Mali : ODHD, 126 p.

Ouédraogo, M., Dembélé, Y., \& Somé, L. (2010). Perceptions et stratégies d'adaptation aux changements des précipitations : cas des paysans du Burkina Faso. Science et changements planétaires/Sécheresse, 21(2), 87-96.

Ouoba, P. A. (2013). Changements climatiques, dynamique de la végétation et perception paysanne dans le Sahel burkinabè (Burkina Faso) (Doctoral dissertation, Thèse de Doctorat unique de Géographie, Département de Géographie, Université de Ouagadougou).

Pauw, P. (2013). The role of perception in subsistence farmer adaptation in Africaenriching the climate finance debate, International Journal of Climate Change Strategies and Management, 5(3).
Sanogo, S., Fink, A. H., Omotosho, J. A., Ba, A., Redl, R., \& Ermert, V. (2015). Spatio-temporal characteristics of the recent rainfall recovery in West Africa. International Journal of Climatology, 35(15), 4589-4605.

Sivakumar, M. V. K. (1988). Predicting rainy season potential from the onset of rains in southern Sahelian and Sudanian climatic zones of West Africa. Agricultural Forest and Meteorology, 42, 295-305.

Slimani, I. (2014). Constitution d'un Echantillon : Conseils Méthodologiques, fiche pratique : Constitution d'un échantillon, $7 \mathrm{p}$.

Stern, R., Rijks, D., Dale, I., \& Knock J. (2006). INSTAT (interactive statistics) climate guide. pp 330.

Taifa, I. W., \& Desai, D. A., (2016). Studentdefined Quality by Kano Model: A Case Study of Engineering Students in India, International Journal for Quality Research, 10(3) 569-582.

Tessema, I., \& Simane, B. (2020). Smallholder Farmers' perception and adaptation to climate variability and change in Fincha sub-basin of the Upper Blue Nile River Basin of Ethiopia. GeoJournal. https://doi.org/10.1007/s10708020-10159-7.

Traoré, S. S., Diakité, C. H., Diawara, M., \& Traoré, A. (2019). Cartographie des potentialités dans le terroir de Benguéné (Vieux Bassin Cotonnier), in Soumaré M. (éd), Atlas des zones cotonnières du Mali, deuxième édition, IER-CIRAD, pp 53.

Ulrich, C. S. Y., Pierre, Vissoh. V., Guibert, H., Agbossou, E. K., \& Afouda, A. A. (2015). Relation entre perceptions paysannes de la variabilité climatique et observations climatiques au Sud-Bénin, Vertigo, la revue électronique en science de l'environnement, 13 (3) $20 p$.

Zhang, W., Brandt, M., Guichard, F., Tian, Q., \& Fensholt, R. (2017). Using long-term daily satellite-based rainfall data (1983-2015) to analyze spatio-temporal changes in the sahelian rainfall regime. Journal of hydrology, 550, 427-440.

34 | This work is licensed under a Creative Commons Attribution 4.0 International License. 